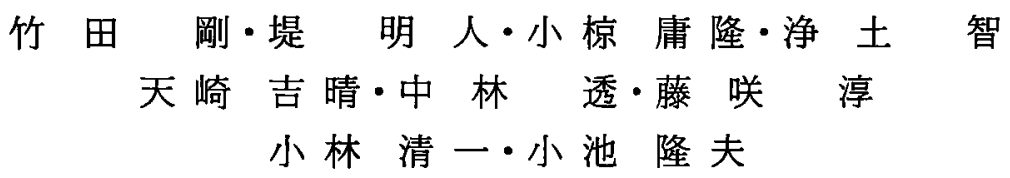

Jpn. J. Clin. Immun., 18 (3) : 303 307, 1995.

\title{
A case of mixed connective tissue disease with acute interstitial pneumonitis
}

Tsuyoshi Takeda, Akito Tsutsumi, Nobutaka Ogura, Satoshi Jodo, Yoshiharu Amasaki, Tohru Nakabayashi, Atsushi Fujisaku, Seiichi Kobayashi and Takao Koike

Department of Internal Medicine II, Hokkaido University School of Medicine

\section{【Summary】}

A 43-years-old woman was admitted to the Hokkaido University Hospital because of high fever, muscle weakness and dyspnea in May 1993. She had had muscle weakness of upper extremities since December 1992. She had developed swollen hand, polyarthralgia and Raynaud's phenomenon. High fever and severe dyspnea developed in May 1993. Chest roentogenogram was normal in April 1993. Physical examination showed Velcro rales in both lower lung fields. Her laboratory data showed incrased muscle enzymes, high titers of anti-nuclear-antibody (1:1280) and anti-RNP-antibody (index 199.4 (normal <7)). Anti -DNA, anti-Sm and anti-Jo-1-antibodies were all negative. Blood gas analysis showed severe hypoxemia. Chest roentogenogram revealed diffuse bilateral interstitial infiltrates prominent in the bases. Diagnosis of mixed connective tissue disease with acute interstitial pneumonitis was made. She was treated with steroid pulse therapy (methylprednisolone 1 $\mathrm{g} \times 3$ days) followed by high dose oral prednisolone $(60 \mathrm{mg} /$ day), and diffuse interstitial infiltrates disappeared within one week. Prednisolone could be tapered to $17.5 \mathrm{mg} /$ day without relapse.

Acute interstitial pneumonitis is a rare complication of mixed connective tissue disease, but may be life threatning. In such cases, high dose steroid therapy should be started without delay. 
Key words : acute interstitial pneumonitis, mixed connective tissue disease (MCTD), steroid therapy

\section{【概 要】}

症例は 43 歳，女性. 1992 年 12 月頃より両上肢の脱力感が出現した。次第に手指の腫脹，レイノー現象, 顔 面の紅玟, 多関節痛を認めるようになったため 1993 年 4 月某医を受診した。抗核抗体・抗 RNP 抗体強陽性より 混合性結合組織病 (MCTD) が疑われたが, 胸部X線写真に異常はなかった. 同年 5 月, 発熱, 下肢の脱力感, 呼吸苦が出現したため当科を受診, 両側背部に Velcro ラ音を聴取し, 筋原性醉素の上昇, 著明な低酸素血症, 胸部画像診断で下肺野優位の粒状網状影を認めた.MCTDの急性増悪に伴う急性間質性肺炎と診断しステロイ ドパルス療法を施行, 低酸素血症および胸部X線所見は改善し, 筋原性醭素も正常化した.

MCTD で間質性肺炎をきたす場合，多くは慢性に進行し，本症例の様に急激に悪化する例は極めてまれであ る.しかし，このような例では死の転帰をとることもあり速やかにステロイドの大量投与を行うことが重要であ ると思われた。

\section{I . 緒 言}

混合性結合組織病（以下 MCTD と略す）では，間 質性肺炎の合併頻度は比較的高いといわれているが, 多くは慢性の経過をとり，急性の間質性肺炎をきたす 例は極めてまれである.今回われわれは急激な経過で 間質性肺炎をきたし，ステロイドパルス療法が著効し た MCTDの1例を経験したので報告する。

\section{II. 症例}

患 者: 43 歳, 女性.

主 訴：呼吸困難, 発熱, 四肢の脱力感.

既往歴：特記すべきことなし。

家族歴：特記すべきことなし.

現病歴：1992 年 12 月頃より両上肢の脱力感が出 現, その後両手指の腫脹, レイノー現象, 顔面の紅

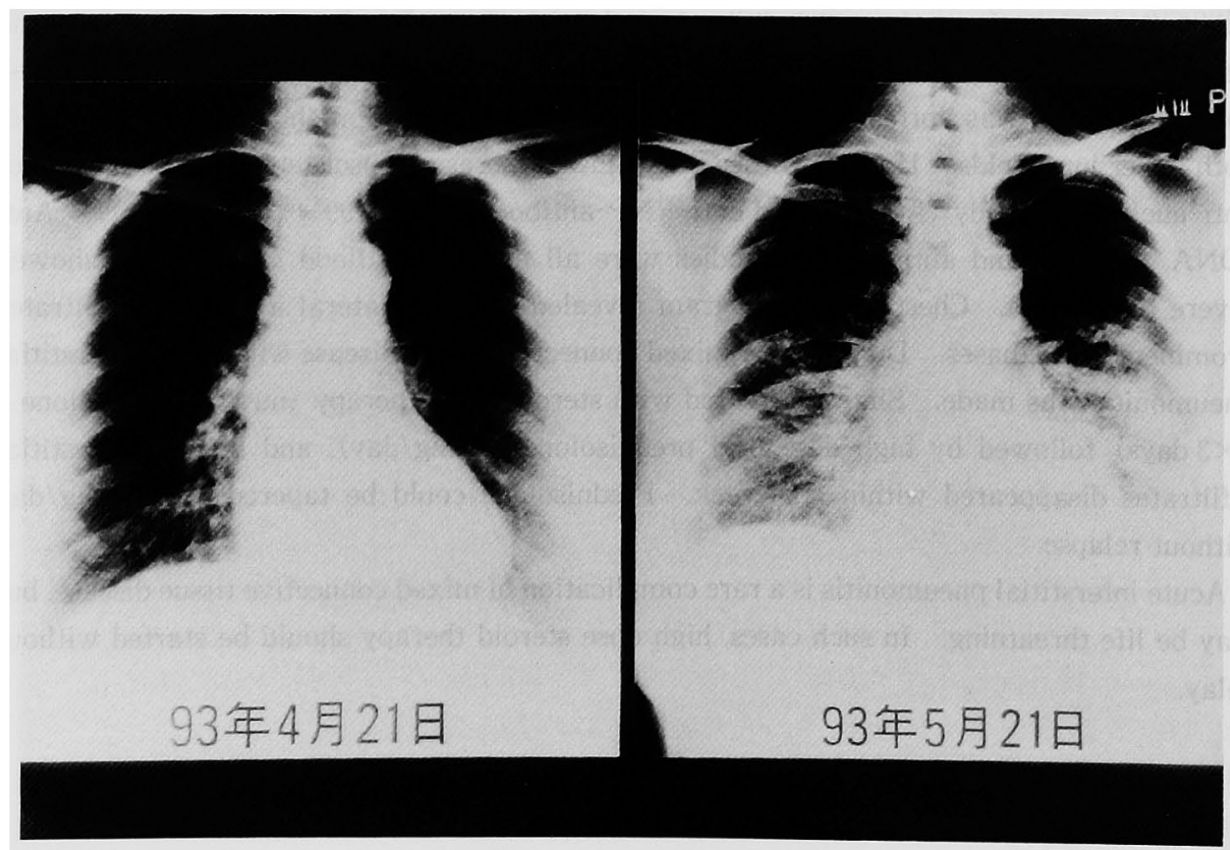

図 1 胸部 $\mathrm{X}$ 線所見

当科入院 1 力月前.（左）入院時. 両側下肺野を中心に粒状網状影をみとめる（右）。 
表 1 入院時検查成績

\begin{tabular}{|c|c|c|c|c|c|}
\hline \multicolumn{2}{|l|}{ 検尿一般 } & \multicolumn{2}{|l|}{ 生化学 } & \multicolumn{2}{|l|}{ 免疫学 } \\
\hline 蛋白 & $( \pm)$ & T.P. & $6.6 \mathrm{~g} / \mathrm{d} l$ & CRP & $20.71 \mathrm{mg} / \mathrm{d} l$ \\
\hline 栯 & $( \pm)$ & Alb. & $43.4 \%$ & $\mathrm{RF}$ & $19 \mathrm{IU} / \mathrm{m} l$ \\
\hline 沈查 & 異常なし & $\alpha 1$ & $5.6 \%$ & LE 細胞 & $(-)$ \\
\hline 検便 & & $\alpha 2$ & $9.6 \%$ & IgG & $3,468 \mathrm{mg} / \mathrm{d} l$ \\
\hline 潜血 & 陰性 & $\beta$ & $6.9 \%$ & IgA & $88 \mathrm{mg} / \mathrm{d} l$ \\
\hline 血沈 & $41 \mathrm{~mm} / \mathrm{h}$ & $y$ & $31.4 \%$ & IgM & $134 \mathrm{mg} / \mathrm{d} l$ \\
\hline \multicolumn{2}{|l|}{ 末梢血 } & T. Bil & $0.4 \mathrm{mg} / \mathrm{d} l$ & \multicolumn{2}{|c|}{$1: 1,280$} \\
\hline$\underline{\mathrm{WBC}}$ & $13,300 / \mathrm{mm}^{3}$ & GOT & $86 \mathrm{IU} / l$ & \multicolumn{2}{|l|}{ (Speckled) } \\
\hline Stab & $4 \%$ & GPT & $48 \mathrm{IU} / l$ & aDNA ab & $5.1 \mathrm{U} / \mathrm{m} l$ \\
\hline Seg & $64 \%$ & $\underline{\mathrm{LDH}}$ & $1,349 \mathrm{IU} / l$ & aRNP $\mathrm{ab}(<7)$ & 199.4 index \\
\hline Lymph & $28 \%$ & 1 & $11.9 \%$ & $\mathrm{aSm} \quad \mathrm{ab}(<7)$ & 2.7 index \\
\hline Mono & $2 \%$ & 2 & $41.9 \%$ & aSSA $\quad a b(<7)$ & 61.6 index \\
\hline Eosino & $1 \%$ & 3 & $27.3 \%$ & aSSB $\quad a b(<10)$ & 10.0 index \\
\hline $\mathrm{RBC}$ & $501 \times 10^{4} / \mathrm{mm}^{3}$ & 4 & $12.3 \%$ & $\mathrm{aSc} 170 \mathrm{ab}(<5)$ & $<0.1$ index \\
\hline $\mathrm{Hb}$. & $14.4 \mathrm{~g} / \mathrm{d} l$ & 5 & $6.5 \%$ & aJo-1 ab & $(-)$ \\
\hline Ht. & $42.8 \%$ & $\mathrm{CPK}$ & $594 \mathrm{IU} / l$ & $\mathrm{C} 3$ & $70 \mathrm{mg} / \mathrm{d} l$ \\
\hline Plt. & $21.9 \times 10^{4} / \mathrm{mm}^{3}$ & (MM 型 & $100 \%)$ & $\mathrm{C}_{4}$ & $42 \mathrm{mg} / \mathrm{d} l$ \\
\hline Reticulo & $88 \%$ & aldolase & $8.3 \mathrm{U} / l$ & CH 50 & $26.6 \mathrm{U} / \mathrm{ml}$ \\
\hline 凝固系 & & $\underline{\text { myoglobin }}$ & $110 \mathrm{ng} / \mathrm{m} l$ & $\mathrm{CIC}$ & \\
\hline $\mathrm{PT}$ & $12.4 \mathrm{sec}$ & Bun & $24 \mathrm{mg} / \mathrm{d} l$ & C1q 法 & $(-)$ \\
\hline APTT & $24.3 \mathrm{sec}$ & $\mathrm{Cr}$ & $0.9 \mathrm{mg} / \mathrm{d} l$ & aC3d 法 & $(-)$ \\
\hline Fibrinogen & n $284.4 \mathrm{mg} / \mathrm{d} l$ & $\mathrm{Na}$ & $134 \mathrm{mEq} / l$ & mRF 法 & $(-)$ \\
\hline FDP & $24.5 \mu \mathrm{g} / \mathrm{d} l$ & $\mathrm{~K}$ & $4.1 \mathrm{mEq} / l$ & $\mathrm{aCL}$ & $(-)$ \\
\hline AT-III & $120 \%$ & $\mathrm{Cl}$ & $103 \mathrm{mEq} / \mathrm{l}$ & STS & $(-)$ \\
\hline 動脈血ガス分 & 子析 & Tcho & $160 \mathrm{mg} / \mathrm{d} l$ & TPHA & $(-)$ \\
\hline $\mathrm{PH}$ & 7.457 & FBS & $157 \mathrm{mg} / \mathrm{d} l$ & HBsAg & $(-)$ \\
\hline$\underline{\mathrm{PO}_{2}} \quad 37$. & $.2 \mathrm{mmHg}$ & & & HCVab & $(-)$ \\
\hline $\mathrm{PCO}_{2}$ & $28.4 \mathrm{mmHg}$ & & & 各種ウイルス抗体価 & \\
\hline$\underline{\mathrm{O}_{2} \text { sat }}$ & $74.4 \%$ & & & & 意な上昇なし \\
\hline
\end{tabular}

斑, 多関節痛が出現した。1993 年 4 月 21 日近医を受 診し，抗 RNP抗体単独陽性によりMCTDを疑われ たが,この際，胸部 X線写真は正常であった（図 1. 左). 無投薬にて経過観察とされたが同年 5 月 9 日よ り $38^{\circ} \mathrm{C}$ 台の発熱, 呼吸困難, 下肢の脱力感が出現し たため 5 月 21 日当科を受診, 入院となった.

入院時現症：身長 $146 \mathrm{~cm}$, 体重 $55 \mathrm{~kg}$, 血圧 160 $102 \mathrm{mmHg}$, 脈拍 $102 / \mathrm{min}$ - 整, 呼吸は努力性. 結膜 に負血・黄染なし. 舌小帯の短縮あり。心雑音はなく, 両下肺に Velcro ラ音を聴取した。腹部に異常なく, 表在リンパ節腫脹は認めない. 爪甲にチアノーゼがあ り，両手指に腫脹を認めた。

入院時検查所見 (表 1・) : 尿糖, 尿蛋白は弱陽性, 血沈の亢進を認めた. 未梢血ては白血球数の増加を認 めたが貟血はなく，血小板数も正常だった，凝固系で はAPTTの短縮, FDPの上昇がみられた. 生化学検
查では高 $\gamma$ グロブリン血症を認めた. CPK は 594 $\mathrm{IU} / l$ と上昇, GOT, LDH, CPK, aldolase, myolobinなどの筋原性酵素も上昇していた. 免疫学 的検査では，CRP は著明に上昇，抗核抗体は 1,280 倍と強陽性, 抗 RNP 抗体もELISA 法て 199.4 (index) と強陽性であったが, 抗 DNA 抗体, 抗 Sm 抗体, 抗 Jo-1 抗体は陰性, 血清補体価も正常 であった。各種ウイルス抗体価に有意の上昇はなく, 動脈血ガス分析では， $\mathrm{PO}_{2} 37.2 \mathrm{mmHg}$ と著明な低酸 素血症を認めた.

胸部X線写真では，両側下肺野を中心に「粒状網 状」陰影を認め, 両側に中等量の胸水の貯留を認めた (図 1.右). 胸部 CTでは, 肺胞内への浸出性の変化 を 1 部認めたが, 病変の主体は間質の浮腫および炎症 であった（図 2 )。

入院後経過：MCTDに伴う急性間質性肺炎と診断 


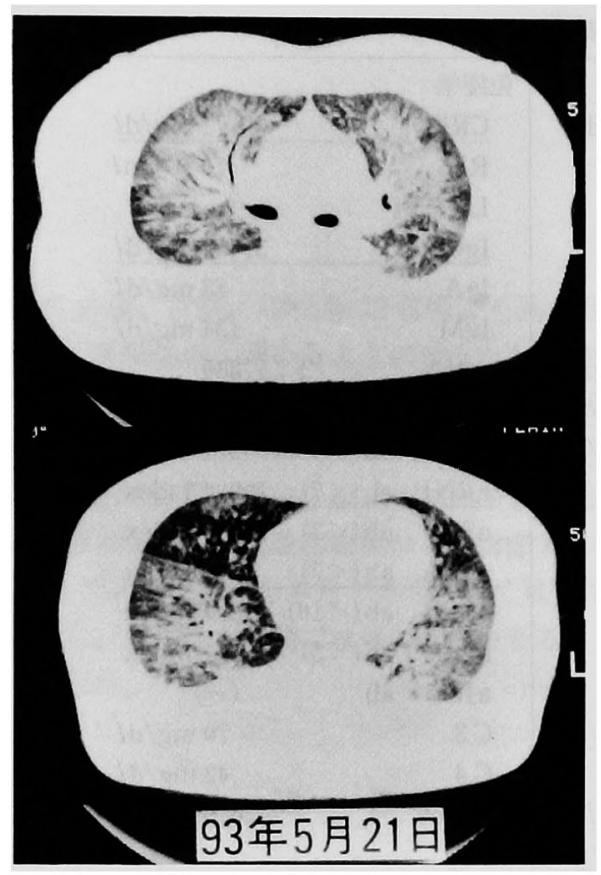

图 2 入院時胸部 CT 所見

間質の浮腫および炎症を認める。また，肺 胞内への浸出性変化も一部に認める.

し，入院後直ちにステロイドパルス療法 (methylprednisolone $1 \mathrm{~g} /$ day 3 日間) を開始, 以後 Prednisolone（以下 PSL と略す） $60 \mathrm{mg} / \mathrm{day}$ を投与した. パルス療法開始後速やかに発熱, 低酸素血症は改善, 胸部 X線所見も約 1 週間で正常化し, CPK をはじめ とする筋原性醉素も速やかに改善した。

呼吸器症状が改善した後に施行した筋電図では, 最 大収縮時の振幅の低下がみられた。また筋生検では， 微小血管の肥厚および間質と筋膜に軽度の炎症細胞浸 潤を認めたが，筋実質への細胞浸潤はなく，明らかな 筋炎としての所見にそしかった。 食道造影では, 食道 の蠕動運動の低下がみられた. 心エコーでは, 肺高血 圧症を示唆する所見はなかった。

以後, PSLを $17.5 \mathrm{mg} /$ day まで溸減したが, 間 質性肺炎の再発は認めず, 筋原性醅素の再上昇もみら れていない.

\section{III. 考 案}

本症例は筋力低下で発症し, 次第に, 手指の腫脹, レイノー現象, 顔面の紅斑, 多関節痛が出現, さらに 発症後 5 カ月という極めて短い経過で間質性肺炎によ り呼吸不全をきたした例と考えられた。この症例の診
断については，1984 年の厚生省 MCTD 診断基準 ${ }^{11} の$ うち共通項目である Raynaud 現象, 手指の腫脹を認 め, 抗 RNP 抗体陽性であり, 加えて全身性エリテマ トーデス様所見, 強皮症様所見, 多発性筋炎様所見を 有したことから MCTD と診断した。

本症例のような急性の経過をとる間質性肺炎は, 多 発性筋炎においてしばしば経験される2).しかし，本 例では間質性肺炎を伴う多発性筋炎で陽性率が高いと いわれている3抗 Jo-1 抗体は陰性であり, 筋生検で も明らかに筋炎の所見がみられなかったことより多発 性筋炎を否定した。さらに，発熱や筋症状の悪化とと もに呼吸不全が出現しており，本症例の間質性肺炎は MCTDの急性増悪に伴って進行したものと考えられ た.

MCTD における肺病変の頻度は約 $20 ８ 0 \%$ と報告 されている 膜炎，肺高血圧症等が知られており，このうち間質性 肺炎は一般に緩徐に発症するといわれている5．本症 例のように発症からわずか 5 力月間という短期間に進 行した例は極めてまれであり，われわれが検索した範 囲では Wiener-Kronish らが報告した 2 例のみであ った6). 1 例は関節痛で発症し, 半年後に間質性肺炎 をきたしたため PSL $40 \mathrm{mg} /$ day を投与，改善がみら れず PSLの増量および cyclophosphamideの併用を 行われたが, 死の転㷌をとった。 また，他の 1 例はレ イノー現象で発症し 9 力月後に呼吸苦が出現, 間質性 肺炎を認め PSL $60 \mathrm{mg} / \mathrm{day}$ の投与で改善している. 一般に MCTD の生命予後は良好といわれているが， 急速に進行する間質性肺炎を呈する MCTD は死の転 帰をとることもあり，本症例のように速やかなステロ イドの大量投与が重要と思われた.

\section{IV. まと め}

急速に間質性肺炎をきたした MCTDの症例を経験 した，MCTDにおける急性の間質性肺炎の報告は過 去に2 例が報告されているのみでまれなものと考えら れた．治療においてはステロイドの大量投与が重要と 思われた。 


\section{文献}

1）粕川禮司・東條 毅・宮脇昌二・他：混合性結 合組織病診断の手引，厚生省特定疾患混合性結 合組織病調査研究班 昭和 58 年度研究報告 書：pp. 79 82, 1984.

2) Franzier, A.R., Miller, R.D. : Interstitial pneumonitis in association with polymyositis and dermatomyositis. Chest, 65(4) : 403 407, 1974.

3) Bernstein, R.M., Morgan, S.H., Chapman, J. et al.: Anti-Jo-1 antibody : a marker for myositis with interstitial lung disease. Br. Med. J., 289 : 151 152, 1984.
4) Prakash, U.B.S. : Lungs in mixed connective tissue disease. J. Thorac. Imaging, $7(2): 55$ $\sim 61,1992$.

5) Sullivan, W.D., Hurst, D.J., Harmon C.E. et al.: A prospective evaluation emphasizing pulmonary involvement in patients with mixed connective tissue disease. Medicine, 63:92 107, 1984.

6) Wiener-Kronish, J.P., Solinger, A.M., Warnock, M.L. et al. : Severe pulmonary involvement in mixed connective tissue disease. Am. Rev. Respir. Dis., 124 : 499 503, 1984. 